\title{
Pengembangan Model Partisipasi Masyarakat dalam Penyelenggaraan Pemerintahan Desa di Kabupaten Banyumas ${ }^{1}$
}

\author{
Kadar Pamuji, Abdul Aziz Nasihuddin, Riris Ardhanariswari, \\ Supriyanto, dan Sukirman \\ Fakultas Hukum Unsoed- Purwokerto \\ Jln. Prof. Dr. HR. Boejamin 708 - Purwokerto \\ kadarpamuji@yahoo.co.id; aziz_lingk@yahoo.com; ririsardhana@gmail.com; \\ sukirman.hukum@gmail.com
}

\author{
Received: 7 Juli 2017; Accepted: 14 Februari 2018; Published: 5 Juni 2018 \\ DOI: 10.20885/iustum.vol24.iss4.art6
}

\begin{abstract}
The enactment of Law Number 6 of 2014 on the Village has provided opportunities for the development of democratic village autonomy. This study focused on two issues, first how is the implementation of village community participation in the implementation of village governance?, second how is the implication of the implementation of Law Number 6 of 2014 on Village on the development of model for community participation in the implementation of village government? This was an empirical legal study which was conducted in three sub-districts namely Sumpiuh, Banyumas and Gumelar sub-districts. The findings showed that first, community participation is manifested in the form of direct interaction through rembug desa at RT (neighborhood) level, or through representation such as BPD, PKK. Second, community participation leads to representation, so that it is necessary to improve the quality of human resources of community institutions in the village.
\end{abstract}

Keywords: Development; model; participation; village governance

\section{Abstrak}

Diundangkannya UU No. 6 Tahun 2014 tentang Desa memberi peluang bagi pengembangan otonomi desa yang demokratis. Penelitian ini mengangkat dua permasalahan, yakni pertama bagaimana pelaksanaan partisipasi masyarakat desa dalam penyelenggaraan pemerintahan desa?, kedua bagaimanakah implikasi pelaksanaan Undang-Undang No. 6 Tahun 2014 tentang Desa terhadap pengembangan model partisipasi masyarakat dalam penyelenggaraan pemerintahan desa? Metode penelitian yuridis empiris. Penelitian dilakukan di tiga kecamatan yaitu Kecamatan Sumpiuh, Banyumas dan Gumelar. Hasil penelitian menunjukkan bahwa pertama, partisipasi masyarakat diwujudkan dalam bentuk interaksi langsung melalui rembug desa di tingkat $\mathrm{RT}$, maupun melalui unsur keterwakilan seperti BPD, PKK. Kedua, partisipasi masyarakat mengarah pada bentuk keterwakilan, maka disarankan untuk dilakukan peningkatan kualitas SDM lembaga kemasyarakatan di desa.

Kata-kata Kunci : Pengembangan; model; partisipasi; pemerintahan desa

${ }^{1}$ Artikel ini merupakan hasil penelitian dari Riset Institusional Dana BLU Unsoed dengan SK Ketua LPPM Unsoed Purwokerto Nomor : 2154/UN23.14/PN.01.00/2016 tentang Pelaksana Riset Institusi Unsoed Anggaran Tahun 2016. 


\section{Pendahuluan}

Desa atau yang disebut dengan nama lain selanjutnya disebut desa adalah kesatuan masyarakat hukum yang memiliki batas-batas wilayah yurisdiksi, berwenang untuk mengatur dan mengurus kepentingan masyarakat setempat. ${ }^{2}$ Landasan pemikiran dalam pengaturan mengenai desa adalah keanekaragaman, partisipasi, otonomi asli, demokratisasi dan pemberdayaan masyarakat.

Pada 15 Januari 2014, Pemerintah telah menetapkan Undang-Undang Nomor 6 Tahun 2014 tentang Desa. Undang-Undang tentang Desa tersebut dibuat untuk menggantikan Peraturan Perundang-Undangan terkait dengan desa yang sudah ada sebelumnya. Pasal 23 UU No. 6 Tahun 2014 memberikan penegasan, bahwa Pemerintahan Desa diselenggarakan oleh Pemerintah Desa, yang dimaksud pemerintah desa, menurut ketentuan Pasal 1 angka 3 UU No. 6 Tahun 2014, adalah Kepala Desa atau yang disebut dengan nama lain dibantu perangkat desa sebagai unsur penyelenggara Pemerintahan Desa.

Peluang bagi pengembangan otonomi desa yang demokratis tampak terbuka lebar dimana masyarakat berhak memperoleh informasi, melakukan pemantauan serta melaporkan semua aktivitas yang dinilai kurang transparan kepada pemerintah desa dan BPD (Badan Permusyawaratan Desa). Sehubungan dengan itu keberadaan dan kepedulian masyarakat desa dalam mengurus rumah tangganya sendiri menjadi perhatian utama bagi seluruh penyelenggara pemerintahan desa. Prinsip pembangunan yang berpusat pada rakyat menegaskan masyarakat harus menjadi pelaku utama dalam pembangunan. Pemberdayaan masyarakat dalam pembangunan diharapkan menumbuhkan pertisipasi masyarakat dalam melaksanakan pembangunan. ${ }^{3}$

Hal yang senada dikemukakan oleh Dea Deviyanti bahwa dalam pelaksanaan pembangunan, partisipasi masyarakat sangat diharapkan dalam setiap tahapan pembangunan yang dimulai dari tahap perencanaan, tahap pelaksanaan, tahap

2 Undang-Undang No. 6 Tahun 2014 tentang Desa Pasal 1 butir 1 memberikan pengertian Desa adalah kesatuan masyarakat hukum yang memiliki batas wilayah yang berwenang untuk mengatur dan mengurus urusan pemerintahan, kepentingan masyarakat setempat berdasarkan prakarsa masyarakat, hak asal usul, dan/atau hak tradisional yang diakui dan dihormati dalam sistem pemerintahan Negara Kesatuan Republik Indonesia.

3 Fathurrahman Fadil, 'Partisipasi Masyarakat Dalam Musyawarah Perencanaan Pembangunan Di Kelurahan Kotabaru Tengah”, Jurnal Ilmu Politik dan Pemerintahan Lokal, Vol. II Edisi 2, Juli-Desember 2013, Program Magister Ilmu Pemerintahan Fisip, Unlam, hlm. 253. 
pemanfaatan dan tahap evaluasi. Melalui pembangunan yang berbasis partisipasi masyarakat ini akan dapat dilaksanakan pembangunan daerah yang benar-benar sesuai dengan kebutuhan dan aspirasi masyarakat. ${ }^{4}$

Permasalahan justru muncul seiring dengan adanya perubahan pengaturan tata pemerintahan desa, dengan kata lain perubahan terhadap tata pemerintahan desa dapat berdampak pada perubahan pola sikap masyarakat maupun perubahan fungsi kelembagaan masyarakat. Satu hal yang tidak dikehendaki adalah munculnya sikap apatis dan ketidakpedulian masyarakat terhadap penyelenggaraan pemerintahan desa.

Sebagaimana dikemukakan oleh Muhammad Faisal Asariansyah bahwa dari tahun ke tahun, proses pembangunan yang dilakukan pemerintah ternyata juga semakin dikritisi oleh masyarakat, dan dampaknya, tumbuh bias-bias negatif dari masyarakat terhadap proses pembangunan yang sedang atau akan dilakukan. Sekurang-kurangnya, ternyata masyarakat ada yang tidak peduli dengan proses pembangunan yang sedang dan akan dilakukan. Ini jelas menunjukkan adanya sebuah gejala kurangnya partisipasi masyarakat terhadap agenda pembangunan. ${ }^{5}$

Amanat untuk pengembangan partisipasi masyarakat desa tertuang di dalam Pasal 18 ayat (7) dan Pasal 18B ayat (2) Undang-Undang Dasar Negara Republik Indonesia 1945, salah satunya yaitu mendorong prakarsa, gerakan, dan partisipasi masyarakat desa untuk pengembangan potensi dan aset desa guna kesejahteraan bersama.

Materi muatan Undang-Undang Desa 2014 memuat banyak kesempatan bagi masyarakat untuk berpartisipasi di dalam penyelenggaraan pemerintahan dan pembangunan desa. Pasal 3 secara tegas menyebutkan bahwa pengaturan desa salah satunya berasaskan pada asas partisipasi yaitu turut berperan aktif dalam suatu kegiatan, kemudian di dalam Pasal 4 huruf d mencantumkan bahwa

${ }^{4}$ Dea Deviyanti, "Studi Tentang Partisipasi Masyarakat Dalam Pembangunan Di Kelurahan Karang Jati Kecamatan Balikpapan Tengah", e-Journal Administrasi Negara, 2013, 1 (2): 380-394 ISSN 0000-0000, Fakultas Ilmu Sosial dan Ilmu Politik, Universitas Mulawarman, hlm. 381 http://www.ejournal.an.fisip-unmul.ac.id, diakses tanggal 23 Februari 2017.

5 Muhammad Faisal Asariansyah dkk, "Partisipasi Masyarakat Dalam Pemerataan Pembangunan Infrastruktur Jalan (Studi Kasus Di Kecamatan Lawang Kabupaten Malang)", Jurnal Administrasi Publik (JAP), Vol.1, No. 6, Fakultas Ilmu Administrasi, Universitas Brawijaya, Malang, 2013, hlm. 1141. 
pengaturan tentang desa bertujuan mendorong prakarsa, gerakan, dan partisipasi masyarakat desa untuk pengembangan potensi dan Aset Desa guna kesejahteraan bersama, bahkan di dalam Pasal 68 ayat (2) huruf e bahwa masyarakat wajib berpartisipasi dalam berbagai kegiatan di desa.

Pasal 82 ayat (5) UU Desa menyebutkan bahwa dalam rangka pengawasan pelaksanaan pembangunan desa, maka masyarakat desa berpartisipasi dalam Musyawarah Desa untuk menanggapi laporan pelaksanaan Pembangunan Desa. Musyawarah desa merupakan instrumen yang sangat penting dalam penyelenggaraan pemerintahan dan pembangunan di desa. Baik UU desa maupun peraturan pelaksanannya mencantumkan bahwa roda penyelenggaraan pemerintahan dan pembangunan desa diawali dengan musyawarah desa.

\section{Rumusan Masalah}

Berdasarkan uraian tersebut di atas, maka dapat diketengahkan beberapa permasalahan, Pertama, bagaimakah pelaksanaan partisipasi masyarakat dalam penyelenggaraan pemerintahan desa? Kedua, bagaimanakah implikasi pelaksanaan Undang-Undang No. 6 Tahun 2014 tentang Desa terhadap pengembangan model partisipasi masyarakat dalam penyelenggaraan pemerintahan desa?

\section{Tujuan Penelitian}

Tujuan diadakannya penelitian ini adalah untuk mengidentifikasi isu permasalahan yang berkaitan dengan partisipasi masyarakat dalam pemerintahan desa yang sudah ada berdasarkan UU No. 6 Tahun 2014 serta implikasinya terhadap model dengan partisipasi masyarakat dalam penyelenggaraan pemerintahan desa berdasarkan UU No. 6 Tahun 2014.

\section{Metode Penelitian}

Penelitian ini merupakan penelitian yuridis empiris. Penelitian ini menggunakan pendekatan kualitatif terkait keyakinan peneliti sesuai pengalaman penelitian dan sifat permasalahan. Alasan penggunaan kualitatif karena memiliki kelebihan dalam mengkonstruksikan realitas sosial, makna budaya, mempunyai fokus pada proses interaktif maupun peristiwa. ${ }^{6}$

\footnotetext{
${ }^{6}$ Lawrence Newman, Social Research Methods: Qualitative and Quantitative Approachs, Allyn and Bacon, Boston,
} 
Lokasi penelitian di Kabupaten Banyumas dengan sasaran penelitian di 3 kecamatan yaitu Kecamatan Sumpiuh, Kecamatan Banyumas dan Kecamatan Gumelar. Dipilihnya ketiga kecamatan tersebut dengan pertimbangan lokasi kecamatan yaitu Kecamatan Sumpiuh sebagai kecamatan disebelah timur wilayah Kabupaten Banyumas, Kecamatan Banyumas sebagai kecamatan yang berada dekat dengan pusat pemerintahan kabupaten dan Kecamatan Gumelar sebagai wilayah kecamatan yang berada di sebelah barat wilayah Kabupaten Banyumas. Dari ketiga kecamatan tersebut, masing-masing kecamatan dipilih 3desa sebagai sasaran penelitian.

Penelitian ini menggunakan teknik pengumpulan data dengan menggunakan metode wawancara dan Focus Group Discussion (FGD) yaitu teknik pengumpulan data yang digunakan untuk meminta tanggapan/permasalahan kelompok. Studi dokumentasi, yaitu teknik merekam peristiwa dari kebijakan yang relevan, dan peraturan perundang-undangan terkait.

Data yang diperoleh dianalisis dengan menggunakan analisis kualitatif. Analisis kualitatif berkaitan dengan data berupa kata atau kalimat yang dihasilkan dari objek penelitian serta berkaitan dengan kejadian yang melingkupi sebuah objek penelitian. Menurut Bogdan dan Biglen analisis data kualitatif adalah upaya yang dilakukan dengan jalan bekerja dengan data, mengorganisasikan data, memilah-milahnya menjadi satuan yang dapat olah, mensintesiskan, mencari dan menemukan pola, menemukan apa yang penting dan apa yang dipelajari dan memutuskan apa yang dapat diceritakan kepada orang lain. ${ }^{7}$

Pengolahan dan analisis data dilakukan pada saat pengumpulan data secara berkelanjutan. Diawali dengan proses klarifikasi data agar tercapai konsistensi, dilanjutkan dengan langkah abstraksi teoritis terhadap informasi dan fakta, yang menghasilkan pernyataan-pernyataan yang mendasar. Data yang diperoleh dari hasil penelitian disajikan dalam bentuk teks naratif dan disusun secara sistematis sebagai kesatuan yang utuh.

1994, hlm. 14.

${ }^{7}$ Lexy J. Moleong, Metodologi Penelitian Kualitatif, PT. Remaja Rosdakarya, Bandung, 2009, hlm. 248. 


\section{Hasil Penelitian dan Pembahasan}

\section{Pelaksanaan Partisipasi Masyarakat}

Kebijakan pembangunan partisipasi masyarakat secara umum ditujukan untuk meningkatkan kesadaraan masyarakat akan pentingnya dukungan masyarakat dalam pelaksanaan pembangunan. Langkah pemberdayaan masyarakat bertujuan untuk menggali, mengembangkan dan mengelola sumber daya yang dimiliki desa.

Hasil penelitian di Kecamatan Sumpiuh menunjukan bahwa kebijakan peningkatan partisipasi masyarakat dalam berswadaya pembangunan, adalah untuk meningkatkan kesadaraan masyarakat akan pentingnya dukungan masyarakat dalam pelaksanaan pembangunan khususnya adalah swadaya masyarakat. Memberdayakan seluruh lapisan masyarakat untuk menggali, mengembangkan dan mengelola sumber daya yang dimiliki Desa, adalah pembangunan pemberdayaan masyarakat yang berorientasi terhadap persamaan gender.

Partisipasi masyarakat dalam berswadaya pembangunan, adalah untuk meningkatkan kesadaraan masyarakat akan pentingnya dukungan masyarakat. Swadaya masyarakat menjadi bentuk partisipasi dan keterlibatan masyarakat dalam pembangunan desa. Setiap elemen masyarakat sudah memiliki wakil-wakil sendiri secara kelembagaan, seperti unsur atau elemen wanita terwakili dalam dasawisma, elemen pemuda terwakili dalam karangtaruna, jadi, ketika ada musyawarah desa maka melalui kelembagan perwakilan-perwakilan inilah akan merumuskan hasil-hasil untuk desanya.

Koordinasi yang baik selama ini antara Pemerintah Desa dengan BPD berdampak positif pada partisipasi masyarakat dalam hubungannaya dengan acara-acara yang diadakan oleh desa, baik dalam pembangunan fisik maupun yang lainnya. Partisipasi yang dilakukan oleh masyarakat dapat langsung disalurkan kepadan BPD dan selanjutnya dari BPD akan dirapatkan dengan pemerintah Desa, akan tetapi pemerintah desa juga tidak menutup kemungkinan aspirasi dari masyarakat langsung ke pemerintah desa, selanjutnya akan dirembuk bersama dengan BPD. Masyarakat selalu dilibatkan dalam segala acara desa, setiap ada bantuan untuk desa langsung dialokasikan kepada subjek-subjek dan objek yang 
bersangkutan, mereka rembuk bersama. Masyarakat masih sangat patuh dengan anjuran dan perintah dari kepala desa untuk perbaikan desa. Gotong royong masih terjaga dan tetap lestari sama seperti sebelum adanya aturan khusus tentang desa, yang menganggarkan desa mendapat dana sehingga masyarakat sulit diajak partisipasi, nyatanya di desa ini gotong royong masih tertata rapi dan penokohan tokoh sebagai panutan masih dianggap semangat penggeraknya. ${ }^{8}$

Badan Permusyawaratan Desa sebagai mitra pemerintah desa rata-rata berjumlah 9 orang. Anggota BPD rata-rata lulusan SLTA dan kebanyakan adalah mereka yang ditokohkan dalam masyarakat sehingga pengaruh ke warga dalam menjalin aspirasi dan mengembangkan serta memberdayakan masyarakat lebih efektif. BPD dalam menjalankan fungsi aspirasi masyarakat biasanya dilakukan dalam agenda-agenda rutin pertemuan RT/RW. Di desa masih terdapat budaya selapanan yaitu pertemuan rutin masyarakat yang dilakukan dalam kurun waktu 40 hari sekali. Dalam pertemuan-pertemuan seperti inilah aspirasi dari masyarakat bisa diangkat disalurkan lewat RT/RW ke BPD dan dari BPD akan dirembuk bersama pemerintah Desa. Masyarakat masih antusias, partisipasinya masih bagus baik dalam bentuk tenaga maupun dalam bentuk uang, masyarakat sangat menyambut baik setiap program pemerintah Desa. Pemerintah Desa pun dalam menjalankan pemerintahannya mengedepankan wujud pelayanan langsung ke masyarakat. Masyarakat diajak aktif bersama untuk membangun desa, karena jika hanya mengandalkan uang dari pusat dengan proses pencairannya yang lama, maka pembangunan tidak bisa berjalan efektif. Sehingga partisipasi masyarakat masih sangat dibutuhkan di sini.

Bentuk partisipasi lain yang ada di desa yaitu dari masyarakat menyampaikannya di forum rapat RT setelah itu ketua RT bersama ketua RW membawa ke forum desa bersama BPD. Partisipasi masyarakat masih berjalan baik, namun demikian tidak dapat dipungkiri bahwa untuk wilayah desa tertentu khususnya wilayah desa yang berdekatan dengan wilayah kota, grubyug warga atau yang sering disebut dengan kerja bakti atau gotong royong yang selama ini

\footnotetext{
${ }^{8}$ Informasi dari hasil wawancara dengan Abdul Qudus, Camat Sumpih, Kabupaten Banyumas, pada Rabu, tanggal 11 Mei 2016 jam 10.00 bertempat di Kantor Kecamatan Sumpiuh.
} 
dilakukan, sudah mulai terkikis. Dalam banyak hal warga lebih banyak mengandalkan dana dari desa, bahkan untuk pembuatan infrastruktur desa seperti pembuatan jalan setapak atau pavingisasi jalan setapak, masyarakat tidak membantu kecuali ketika diberi upah dari proyek pengadaan infrastruktur desa tersebut.

Hasil penelitian di Kecamatan Banyumas yang merupakan kecamatan paling dekat dengan pusat pemerintahan kabupaten menunjukan bahwa di wilayah ini bentuk partisipasi masyarakat dalam pemerintah sangat terlihat dengan adanya perwakilan dari setiap elemen masyarakat, seperti elemen perempuan yang diwakili PKK, unsur petani yang diwakili Kelompok Tani, dan sebagainya. Dari model di atas tergambar bahwa penyerapan aspirasi masyarakat melalui perwakilan, begitupun partisipasi masyarakat dalam pemerintahan diwakili oleh kelompok-kelompok perwakilan tersebut.

Kecamatan Banyumas sebagai wilayah yang paling dekat dengan pusat pemerintahan kabupaten partisipasi masyakat masih terpelihara, baik terhadap program pembangunan yang direncanakan pemerintah, pemerintah kabupaten maupun pemerintah desa. Masyarakat masih giat bergotong royong saling membantu tanpa dibayar untuk menyelesaikan program pembangunan. Dalam menyalurkan aspirasi masyarakat dapat melalui RT, RW, BDP atau dapat juga langsung ke pemerintah Desa. Di sini terlihat adanya partisipasi aktif dari warga terhadap pembangunan dan disamping itu terdapat lembaga perwakilan yang mewadahi masyarakat dalam penyampaian aspirasi warga terhadap program pembangunan dan pemerintahan serta pemberdayaan masyarakat seperti BPD, RT, RW dan lain-lain. Program-program pembangunan yang ada di desa sangat menggambarkan tingkat partisipasi masyarakat. Dalam program pembangunan inilah efektifitas keterlibatan masyarakat berpartisipasi dalam program-program desa. ${ }^{9}$

9 Informasi dari hasil wawancara dengan Ahmad Suryanto, Camat Banyumas, Kabupaten Banyumas, pada hari Selasa, tanggal 17 Mei 2016 jam 10.00 bertempat di Kantor Kecamatan Banyumas. 
Sebagian besar penduduk Desa di wilayah Kecamatan Banyumas merupakan penduduk asli Desa yang mempunyai rasa kekerabatan dan kekeluargaan yang masih tinggi. Dalam masyarakat kegiatan gotong royong seperti sambatan, kerja bakti lingkungan, hajatan, termasuk dalam kegiatan program pembangunan infrastruktur Desa.

Wilayah Kecamatan Gumelar adalah wilayah kecamatan di sisi barat kabupaten Banyumas yang berada di atas ketinggian batu kapur sehinga struktur tanahnya rata-rata tandus. Hasil penelitian di wilayah Kecamatan Gumelar diperoleh informasi bahwa partisipasi masyarakat masih terpelihara dengan baik. Masyarakat masih antusias ketika dilibatkan dalam pembangunan seperti dalam bentuk tenaga dan makanan.

Alur penyerapan partisipasi masyarakat dimulai dengan musyawarah dusun, yang tujuannya adalah menggali masalah dan potensi yang berkaitan dengan hak dasar yang ada di tingkat dusun. Yang terlibat dalam musyawarah adalah Ketua RW yang mewakili RT, unsur profesi, unsur perempuan, unsur lembaga, unsur pemerintah, dan Perwakilan BPD. Dari hasil Musyawarah kemudian dilakukan lokakarya desa yang tujuannya adalah mengelompokkan, menggabungkan, dan memverifikasi masalah dan potensi hasil penjaringan ditingkat dusun serta mempelajari sketsa desa, kalender musim dan kelembagaannya. Yang dilibatkan disini seperti delegasi dusun, unsur profesi, perwakilan perempuan, unsur lembaga desa, pemerintah dan perwakilan BPD. Terkait dengan peraturan Pusat, masih sedikit kebingungan dengan adanya tarik ulur aturan yang dibuat oleh kementrian Desa, dengan peraturan yang dikeluarkan oleh kementrian Dalam Negeri. Sampai saat ini belum terkesan ada penurunan tingkat gotong royong dan partisipasi dari masyarakat setelah aturan baru terkait Desa ditetapkan. ${ }^{10}$

Secara umum area partisipasi masyarakat di Kecamatan Gumelar diwujudkan dalam bentuk Musyawarah Dusun yang tujuan menggali masalah dan potensi yang berkaitan dengan hak dasar yang ada di tingkat dusun, yang terlibat

${ }^{10}$ Informasi dari hasil wawancara dengan Suparwoko, PJ. Camat Gumelar, Kabupaten Banyumas, pada hari Rabu, tanggal 25 Mei 2016 jam 10.00 bertempat di Kantor Kecamatan Gumelar. 
disini diantaranya Perwakilan RT, Unsur Profesi, Unsur orang Miskin, Unsur Perempuan, Unsur lembaga, Unsur pemerintah, dan perwakilan BPD, kemudian Lokakarya Desa yang tujuannya adalah mengelompokan, menggabungkan, dan memferifikasi masalah dan potensi hasil penjaringan ditingkat dusun serta mempelajari sketsa dasa, kalender musim dan kelembagaannya, yang dilibatkan disini seperti Delegasi dusun, unsur profesi, orang miskin, perempuan, lembaga, pemerintah dan perwakilan BPD, kemudian musyawarah rencana pembangunan desa (Musrenbangdes) sebagai sarana untuk merencanakan pembangunan desa.

\section{Implikasi Pengembangan Model Partisipasi Masyarakat}

Desa adalah kesatuan masyarakat hukum yang memiliki kewenangan mengatur dan mengurus kepentingan masyarakat setempat berdasarkan asal-usul dan adat-istiadat setempat yang diakui dalam sistem pemerintahan nasional dan berada di daerah Kabupaten. Desa merupakan institusi yang otonom dengan tradisi, adat istiadat dengan hukum sendiri serta relatif mandiri, otonomi desa merupakan otonomi yang asli, bulat dan utuh serta bukan merupakan pemberian dari pemerintah. Sebaliknya pemerintah berkewajiban menghormati otonomi asli yang dimiliki oleh desa tersebut. ${ }^{11}$ Desa diberikan otonomi untuk mengatur dan mengurus kepentingan masyarakat berdasarkan hak asal-usul, adat istiadat, dan nilai sosial budaya masyarakat desa, serta menetapkan dan mengelola kelembagaan desa. Tentunya untuk menjalankan kesemuanya itu maka pemerintah desa perlu mendapatkan dukungan dana. ${ }^{12}$ Menurut $\mathrm{Y}$ Zakaria, sejatinya desa adalah negara kecil, karena sebagai masyarakat hukum, desa memiliki semua perangkat suatu negara, seperti: wilayah, warga, aturan dan pemerintahan. ${ }^{13}$

Dari hasil penelitian di lokasi penelitian dapat dikatakan bahwa meski komunikasi internal antara Pemerintah Desa, BPD dan unsur lembaga kemasyarakatan berjalan dengan baik, akan tetapi masih terdapat catatan yaitu

${ }^{11}$ HAW Widjaja, Otonomi Desa : Merupakan Otonomi yang Asli, Bulat dan Utub, Jakarta: PT Raja Grafindo Persada, 2008, hlm.165.

12 Nyimas Latifah Letty Aziz, “Otonomi Desa dan Efektivitas Dana Desa”, e-Jurnal Penelitian Politik, LIPI, Vol 13, No 2, Tahun 2016, hlm 193. http://ejournal.lipi.go.id Diakses Tanggal 21 Mei 2017.

13 Y Zakaria, Pemuliban Kebidupan Desa dan UU No 22 Tabun 1999, Dalam Desentralisasi, Globalisasi, dan Demokrasi Lokal, LP3S, Jakarta, 2005, hlm. 332. 
masih belum terciptanya suatu penyelenggaraan pelayanan publik dan tata pemerintahan yang baik. Sejatinya unsur penyelenggara pemerintahan desa, dalam hal ini Pemerintah Desa dan BPD harus memperhatikan kualitas pelayanan kepada masyarakat. Sebagaimana dikatakan oleh Yusnani Hasjimzum, bahwa masyarakat memandang pelayanan publik merupakan hak masyarakat sebagai sarana pemenuhan kebutuhan mendasar masyarakat untuk mencapai kesejahteraan sosial. ${ }^{14}$ Untuk kelembagaan yang ada dalam masyarakat sebagaian masih didominasi oleh orang-orang tertentu yang dalam kesehariannya memang aktif di masyarakat desa, seperti tokoh pemuda, tokoh masyarakat, tokoh agama sehingga dalam implementasinya terkadang masih kurang ada koordinasi dengan anggota lain.

Kendala lain yang dihadapi adalah terkait dengan kemampuan SDM pelaksana seperti perangkat desa, BPD maupun unsur lembaga kemasyarakatan yang masih relatif rendah. Khusus untuk anggota BPD posisinya menjadi dilematis karena disatu sisi anggota BPD dituntut untuk paham akan perkembangan kebijakan pemerintah akan tetapi dilain pihak untuk menjadi anggota BPD tidak dipersyaratkan dengan kualifikasi tertentu bahkan mekanisme perekrutannya juga melalui mekanisme yang sederhana. Untuk lembaga/unsur kemasyarakatan seperti PKK, Karang Taruna, tokoh masyarakat, tokoh agama pada kenyataannya yang dilibatkan adalah mereka-mereka yang tergolong sukarelawan, untuk itu perlu dilakukan penataan semua kelembagaan di desa seperti BPD, PKK, Posyandu, RT/RW, termasuk pemerintah desa. Penataan kelembagaan desa ini menjadi penting mengingat kebijakan UU Desa terkait dengan pelaksanaan musyawarah desa sebagai awal kebijakan desa lebih mengarahkan untuk adanya partisipasi unsur kemasyarakatan atau lembaga kemasyarakatan di desa aatau partisipasi atas dasar keterwakilan.

Penegasan bentuk partisipasi yang mengarah kepada bentuk keterwakilan ditegaskan di dalam Peraturan Menteri Desa, Pembangunan Daerah Tertinggal,

${ }^{14}$ Yusnani Hasjimzum, "Model Demokrasi Dalam Peningkatan Kualitas Pelayanan Publik (Studi Otonomi Daerah Dalam Peningkatan Kesejahteraan Masyarakat Pasca Reformasi)", Jurnal Dinamika Hukum Fak. Hukum Universitas Lampung, Vol.14, No. 13 Edisi September 2014, hlm. 448. 
Dan Transmigrasi (Permendes) No. 2 Tahun 2015 tentang Pedoman dan Tata Tertib Pengambilan Keputusan musyawarah desa dalam Pasal 22 disebutkan bahwa :

(1) Panitia Musyawarah Desa mempersiapkan undangan peserta Musyawarah Desa secara resmi dan secara tidak resmi.

(2) Undangan resmi sebagaimana dimaksud pada ayat (1) ditujukan kepada unsur masyarakat secara perseorangan dan/atau kelompok masyarakat dengan dibubuhi tanda tangan Sekretaris Badan Permusyawaratan Desa selaku ketua panitia Musyawarah Desa.

(3) Undangan tidak resmi sebagaimana dimaksud pada ayat (1) diumumkan secara terbuka melalui media komunikasi yang ada di Desa, seperti: pengeras suara di masjid, papan mengumuman, pesan singkat melalui telepon seluler, surat elektronik (e-mail), situs laman (website) Desa.

(4) Badan Permusyawaratan Desa menyampaikan undangan Musyawarah Desa paling lambat 2 (dua) minggu terhitung sebelum hari dan tanggal penyelenggaraan Musyawarah Desa.

Pasal 23 ayat (2) disebutkan bahwa warga desa yang mendapat informasi undangan secara tidak resmi sebagaimana dimaksud dalam Pasal 22 ayat (2) dan berkehendak hadir sebagai peserta, yang bersangkutan harus mendaftarkan diri kepada panitia Musyawarah Desa paling lambat 7 hari terhitung sebelum hari dan tanggal penyelenggaraan Musyawarah Desa.

Ketentuan tersebut, menunjukan bahwa secara normatif partisipasi dalam pelaksanaan musyawarah desa lebih ditujukan kepada masyarakat dalam bentuk keterwakilan atau biasa disebut dengan unsur masyarakat. Pelibatan masyarakat secara invidu bersifat tidak resmi dengan disertai prosedur tambahan untuk dapat ikut dalam musyawarah desa. Prosedur yang harus dilakukan oleh masyarakat secara individu adalah dengan melakukan pendaftaran kepada panitia musyawarah desa.

Pasal 1 angka 5 UU Desa 2014 mendefinisikan bahwa yang dimaksud dengan “Musyawarah Desa atau yang disebut dengan nama lain adalah musyawarah antara Badan Permusyawaratan Desa, Pemerintah Desa, dan unsur masyarakat yang diselenggarakan oleh Badan Permusyawaratan Desa untuk menyepakati hal yang bersifat strategis." Musyawarah desa adalah musyawarah yang diselenggarakan oleh BPD dengan melibatkan unsur Pemerintah Desa dan unsur masyarakat. Selanjutnya dalam Penjelasan Pasal 54 menyebutkan bahwa 
"Musyawarah Desa merupakan forum pertemuan dari seluruh pemangku kepentingan yang ada di Desa, termasuk masyarakatnya, dalam rangka menggariskan hal yang dianggap penting dilakukan oleh Pemerintah Desa dan juga menyangkut kebutuhan masyarakat Desa yang hasilnya menjadi pegangan bagi perangkat Pemerintah Desa dan lembaga lain dalam pelaksanaan tugasnya".

Yang dimaksud dengan "unsur masyarakat" antara lain adalah tokoh adat, tokoh agama, tokoh masyarakat, tokoh pendidikan, perwakilan kelompok tani, kelompok nelayan, kelompok perajin, kelompok perempuan, dan kelompok masyarakat miskin.

Kalimat penjelasan tersebut diatas terlihat secara tegas bahwa pelibatan masyarakat yang dirumuskan secara normatif adalah pelibatan masyarakat dalam bentuk keterwakilan artinya undang-undang tidak mengatur secara tegas adanya partisipasi masyarakat secara individu. Ketidakjelasan konsep masyarakat bersumber dari tidak adanya pengertian dasar yang dimaksud dengan masyarakat baik di dalam UU No. 6 Tahun 2014 tentang Desa maupun di dalam Peraturan Pemerintah No. 43 Tahun 2014 tentang Pelaksanaan UU Desa. Pada kedua aturan dasar hanya menyebutkan istilah masyarakat desa, pemberdayaan masyarakat, unsur masyarakat tanpa menjelaskan siapa yang dimaksud dengan masyarakat.

Ketidaktegasan konsep masyarakat dujumpai juga di dalam Peraturan Menteri teknis tentang desa baik Peraturan Menteri Dalam Negeri (Permendagri) maupun Menteri Desa, Pembangunan Daerah Tertinggal, Dan Transmigrasi (Permendes). Permendagri yang terkait dengan partisipasi masyarakat adalah Peraturan Menteri Dalam Negeri Republik Indonesia Nomor 114 Tahun 2014 Tentang Pedoman Pembangunan Desa, sedangkan Permendes yang terkait dengan partisipasi masyarakat desa adalah Peraturan Menteri Desa, Pembangunan Daerah Tertinggal, Dan Transmigrasi Republik Indonesia Nomor 2 Tahun 2015 tentang Pedoman Tata Tertib Dan Mekanisme Pengambilan Keputusan Musyawarah Desa.

Sejatinya pembangunan partisipasi masyarakat dalam pelaksanaan pembangunan desa dalam banyak hal dapat mengakomodir kepentingan masyarakat. Pelibatan masyarakat melalui unsur keterwakilan satu sisi mempermudah BPD maupun Pemerintah Desa dalam melaksanakan musyawarah 
desa maupun menampung aspirasi masyarakat, namun disi lain bukan tidak mungkin figur yang hadir sebagai unsur masyarakat untuk mewakili masyarakat tidak mampu menerjemahkan keinginan atau aspirasi masyarakat. Menurut Karjuni Dt Maani bahwa penyelenggara pelayanan publik harus bertanggung jawab dalam menjalankan wewenangnya dengan baik, karena publik (masyarakat) memiliki hak untuk mengontrol dan meminta pertanggungjawaban aparat pemerintah. Dalam kondisi seperti ini tentunya pihak pemerintah desa tidak akan leluasa menggali partisipasi masyarakat. ${ }^{15}$

Secara ideal, partisipasi dalam pelaksanaan penyelenggaraan pemerintahan dan pembangunan desa bukan hanya merupakan hak, tetapi sudah merupakan suatu wujud implementasi penyelenggaraan pemerintahan yang demokratis. Pembangunan partisipasi masyarakat dalam pelaksanaan pembangunan desa akan dapat mengakomodir kepentingan masyarakat yang terkadang masih terabaikan. Terabaikannya kepentingan masyarakat tidak terlepas dari kebijakan pembangunan desa yang selama ini sering bersifat top-down. Pemerintah Desa sebagai pelaksana pembangunan di desa tinggal melaksanakan semua program pembangunan yang secara teknis sudah diatur oleh Pemerintah Pusat atau Pemerintah Daerah.

Prinsip partisipasi menuntut masyarakat harus diberdayakan, diberikan kesempatan dan diikutsertakan untuk berperan dalam proses-proses birokrasi mulai dari tahap perencanaan pelaksanaan dan pengawasan atau kebijakan publik. Partisipasi masyarakat merupakan kontrol adanya kekuasaan yang berlebih agar lebih efektif ditujukan sebesar-besarnya untuk masyarakat dalam konsep good governance. Adanya ruang keterlibatan warga dan kerangka kelembagaan yang sesuai dalam partisipasi turut mendorong pembangunan dan pemerataan. ${ }^{16}$ Keterlibatan masyarakat dalam proses perencanaan pembangunan, perencanaan pembentukan kebijakan, pemantauan dari hasil pembangunan dan keberlakuan suatu kebijakan, adalah suatu hal yang mendorong suksesnya suatu pembangunan yang efektif dan efisien. ${ }^{17}$

\footnotetext{
15 Karjuni Dt. Maani “Transparansi Dan Akuntabilitas Dalam Pelayanan Publik” Jurnal Ilmiah Politik. Kenegaraan, Universitas Negeri Padang, Vol VIII, No. 1, Edisi Oktober 2009, hlm. 48.

16 Fathurrahman Fadil, Ibid., hlm. 255.

17 Tomy M Saragih, "Konsep Partisipasi Masyarakat Dalam Pembentukan Peraturan Daerah Rencana Detail Tata Ruang Dan Kawasan”, Jurnal Sasi Vol. 17 No. 3 Bulan Juli-September 2011, Unpati, hlm. 13.
} 
Kebijakan terhadap penyelenggaraan pemerintah desa yang top-down berdampak pada sikap Kepala Desa selalu tampil dominan, tidak ada upaya untuk mengembangkan sebuah tata pemerintahan yang bersendikan pada transparansi, akuntabilitas, daya tanggap, kepercayaan kebersamaan dan partisipasi. Kondisi seperti ini dalam banyak hal akan memunculkan etos kerja pada perangkat Desa yang kurang baik. Pemerintah Desa akan merasa tidak berkepentingan dengan masyarakat dan bahkan tidak memerlukan partisipasi masyarakat, mereka menganggap bahwa mereka sudah dipercaya dan diserahi mandat oleh Pemerintah Pusat atau Pemerintah Daerah, sehingga tidak perlu bekerja dengan semangat partisipatif dan transparansi, atau harus mempertanggungjawabkan tindakan dan kebijakannya dihadapan publik. Pada pihak lain masyarakat desa tidak terlalu peduli dengan kinerja kepala desa sebagai pemegang kekuasaan desa, sejauh Kepala Desa tidak mengganggu usaha ekonomi yang mereka lakukan.

Kurangnya ruang partisipasi dalam pembangunan dan penyelenggaraan pemerintahan desa akan berimplikasi pada suatu sikap yang menganggap tidak pentingnya prinsip akuntabilitas. Akuntabilitas publik sebenarnya merupakan isu yang sangat penting bagi kehidupan demokrasi di desa, tetapi secara empiris, akuntabilitas tidak terlalu diperhatikan oleh kepala desa. Intervensi pemerintah terhadap penyelenggaraan pemerintahan desa dan ketergantungan desa terhadap bantuan dari pusat maupun pemerintah daerah menjadikan kepala desa lebih perhatian terhadap akuntabilitas administratif daripada akuntabilitas terhadap masyarakat desa.

Transparansi adalah problem lain yang melengkapi kurangnya akuntabilitas pemerintah desa, yang bisa dilihat dari sisi kebijakan, keuangan dan pelayanan administratif. Kebijakan desa umumnya dirumuskan oleh elite desa, yang dipersonifikasi dalam bentuk lembaga perwakilan. Masyarakat desa yang menjadi obyek biasanya kurang mengetahui informasi kebijakan dari proses awal. Pemerintah Desa sudah mengaku berbuat secara transparan ketika melakukan sosialisasi kebijakan kepada warga masyarakat melalui lembaga kemasyarakatan desa. Sosialisasi yang dilakukan oleh Pemerintah Desa sering berlangsung satu 
arah dari pemerintah desa untuk memberi tahu (informasi) dan bukan untuk meminta persetujuan maupun justifikasi dari warga.

Dalam penyelenggaraan pembangunan di desa masih terjadi adanya warga yang tidak memperoleh informasi secara transparan bagaimana program pembangunan disusun dan dikelola serta dilaksanakan. Masyarakat selama ini hanya bisa melihat bahwa disekitar mereka ada pelaksanaan proyek pembangunan fasilitas maupun prasarana umum bagai masyarakat seperti perbaikan jembatan, jalan, saluran air tetapi tidak mengetahui berapa biayanya dan darimana sumber biayanya. Desa tidak mempunyai pemahaman yang memadai tentang partisipasi. Bagi kepala desa, partisipasi adalah bentuk dukungan masyarakat terhadap kebijakan pembangunan pemerintah desa. Pemerintah Desa memobilisasi gotong royong dan swadaya masyarakat (yang keduanya dimasukkan sebagai sumber penerimaan APBDes) untuk mendukung pembangunan desa.

Partisipasi dalam pengertian pelibatan dalam suatu kegiatan adalah merupakan suatu proses yang tidak gampang. Partisipasi sebagai salah satu ciri pembangunan desa adalah partisipasi aktif dari masyarakat desa dalam proses pembangunan tersebut. Partisipasi masyarakat memerlukan usaha pembinaan yang terus menerus agar pembangunan desa mencapai sasaran yang diharapkan.

Secara umum permasalahan yang dihadapi oleh masyarakat dalam berpartisipasi mencakup beberapa hal seperti latar belakang pendidikan maupun tingkat sosial masyarakat yang berbeda. Hal ini akan mempengaruhi tingkat partisipasi masyarakat dalam penyelenggaraan pemerintahan desa. Adanya keengganan masyarakat untuk menegur juga berpengaruh terhadap partisipasi masyarakat, kesibukan atau aktifitas pribadi masyarakat yang berbeda juga ikut berpengaruh terhadap partisipasi masyarakat.

Model alternatif yang dapat dilakukan dalam rangka meningkatan partisipasi masyarakat dalam pemerintahan desa adalah dengan secara aktif melibatkan masyarakat dengan memberikan kesempatan kepada masyarakat untuk mengemukakan idea tau gagasannya (urun rembug), membuka akses maupun kontrol terhadap seluruh proses kegiatan pemerintahan desa dan pembangunan desa. Partisipasi yang dimaksud bukan sekedar formalitas untuk melengkapi syarat bahwa itu harus ada, tetapi yang lebih dikedepankan adalah partisipasi 
secara substansial. Pada akhirnya dengan partisipasi secara substansial ini akan menjadikan masyarakat merasa memiliki terhadap desanya beserta seluruh kegiatan pemerintahannya dan pembangunan desanya, yang nantinya akan memberikan dampak terhadap kesejahteraan bagi masyarakatnya.

\section{Penutup}

Berdasarkan kajian di atas, dapat disimpulkan bahwa pertama, mekanisme pelaksanaan partisipasi masyarakat dalam penyelenggaraan pemerintahan desa diawali dengan melakukan penyusunan perencanaan pembangunan yang dilakukan melalui Musyawarah Perencanaan Pembangunan Desa untuk menetapkan prioritas, program, kegiatan, dan kebutuhan pembangunan desa yang kemudian ditindaklanjuti di tingkat desa dan digunakan sebagai dasar untuk menyusun Rencana Pembangunan Jangka Menengah Desa (RPJMdesa). Partisipasi masyarakat dalam penyelenggaraan pemerintahan diwujudkan dalam bentuk interaksi langsung dengan program pemerintah desa atau melalui unsur keterwakilan di desa.

Kedua, Undang-Undang No. 6 Tahun 2014 tentang Desa lebih mengedepankan model partisipasi melalui unsur keterwakilan. Hal ini akan berimplikasi terhadap model penyusunan Rencana Pembangunan Jangka Menengah Desa (RPJMdes) dan bentuk partisipasi masyarakat dalam penyelenggaraan pemerintahan yang lebih mengakomodir kehadiran masyarakat melalui organisasi atau kelompok perwakilan. Kehadiran masyarakat secara pribadi terkait dengan penyelenggaraan musyawarah desa diakomodir dengan mengundang seseorang yang ditokohkan (tokoh agama, tokoh masyarakat).

Adapun hasil penelitian yang telah diuraikan di atas penulis dapat memberikan sarana. Pelaksanaan partisipasi masyarakat yang sudah berjalan baik perlu ditindaklanjuti dengan e-planning agar transparan sehingga meningkatkan kepercayaan masyarakat terhadap pemerintahan desa. Model keterwakilan adalah model yang cukup baik asal dipilih melalui proses yang demokratis dan ke depan perlu dipikirkan model perwakilan berjenjang di tingkat desa. 


\section{Daftar Pustaka}

\section{Buku}

Moleong, J. Lexy, Metodologi Penelitian Kualitatif, PT. Remaja Rosdakarya, Bandung, 2009.

Newman, Lawrence, Social Research Methods: Qualitative and Quantitative Approachs, Boston: Allyn and Bacon, 1994.

Widjaja, HAW, Otonomi Desa Merupakan Otonomi yang Asli, Bulat dan Utuh, PT Raja Grafindo Persada, Jakarta, 2008.

Zakaria, Y., Pemulihan Kehidupan Desa dan UU No 22 Tahun 1999, Dalam Desentralisasi, Globalisasi, dan Demokrasi Lokal, LP3S, Jakarta, 2005.

\section{Jurnal}

Asariansyah, Muhammad Faisal, dkk., "Partisipasi Masyarakat Dalam Pemerataan Pembangunan Infrastruktur Jalan (Studi Kasus Di Kecamatan Lawang Kabupaten Malang)", Jurnal Administrasi Publik (JAP), Vol. 1, No. 6, Jurusan Administrasi Publik, Fakultas Ilmu Administrasi, Universitas Brawijaya, Malang, 2013.

Aziz, Nyimas Latifah Letty, “Otonomi Desa dan Efektivitas Dana Desa", http://ejournal.lipi.go.id, e-Jurnal Penelitian Politik, LIPI, Vol 13, No 2, Tahun 2016.

Deviyanti, Dea, “Studi Tentang Partisipasi Masyarakat Dalam Pembangunan Di Kelurahan Karang Jati Kecamatan Balikpapan Tengah", e-Journal Administrasi Negara, 2013, 1 (2): 380-394 ISSN 0000-0000, Fakultas Ilmu Sosial dan Ilmu Politik, Universitas Mulawarma. http://www.ejournal.an.fisipunmul.ac.id, diakses tanggal 23 Februari 2017.

Fadil, Fathurrahman, "Partisipasi Masyarakat Dalam Musyawarah Perencanaan Pembangunan Di Kelurahan Kotabaru Tengah", Jurnal Ilmu Politik dan Pemerintahan Lokal, Program Magister Ilmu Pemerintahan, FISIP Universitas Lambung Mangkurat Volume II Edisi 2, Juli-Desember 2013.

Hasjimzum, Yusnani, “Model Demokrasi Dalam Peningkatan Kualitas Pelayanan Publik (Studi Otonomi Daerah Dalam Peningkatan Kesejahteraan Masyarakat Pasca Reformasi)", Jurnal Dinamika Hukum Fak. Hukum Universitas Lampung, Vol.14, No. 13 Edisi September 2014.

Maani, Karjuni Dt., “Transparansi Dan Akuntabilitas Dalam Pelayanan Publik” Jurnal Ilmiah Politik Kenegaraan, Universitas Negeri Padang, Vol VIII, No.1, Edisi Oktober 2009.

Saragih, Tomy M., “Konsep Partisipasi Masyarakat Dalam Pembentukan Peraturan Daerah Rencana Detail Tata Ruang Dan Kawasan", Jurnal Sasi Vol. 17 No. 3 Bulan Juli-September 2011, Unpati.

\section{Perundang-undangan}

Undang-Undang Dasar Negara Republik Indonesia Tahun 1945 
Undang-Undang Nomor 6 tahun 2014 tentang Desa, Lembaran Negara RI Tahun 2014 Nomor 7, Tambahan Lembaran Negara RI Nomor 5495.

Peraturan Pemerintah Nomor 43 Tahun 2014 tentang Peraturan Pelaksanaan Undang Undang Nomor 6 tahun 2014 tentang Desa (Lembaran Negara Republik Indonesia Tahun 2014 Nomor 123, Tambahan Lembaran Negara Republik Indonesia Nomor 5539) sebagaimana telah diubah dengan Peraturan Pemerintah Nomor 47 Tahun 2015 tentang Perubahan Peraturan Pemerintah Nomor 43 Tahun 2014 tentang Peraturan Pelaksanaan Undang Undang Nomor 6 Tahun 2014 tentang Desa (Lembaran Negara Republik Indonesia Tahun 2015 Nomor 157, Tambahan Lembaran Negara Republik Indonesia Nomor 5717).

Peraturan Menteri Dalam Negeri Republik Indonesia Nomor 114 Tahun 2014 tentang Pedoman Pembangunan Desa, Berita Negara Republik Indonesia Tahun 2014 Nomor 2094.

Peraturan Menteri Desa, Pembangunan Daerah Tertinggal, Dan Transmigrasi Republik Indonesia Nomor 2 Tahun 2015 tentang Pedoman Tata Tertib Dan Mekanisme Pengambilan Keputusan Musyawarah Desa, Berita Negara Republik Indonesia Tahun 2015, Nomor 159 